> Innlegg på inntil $\mathbf{4 0 0}$ ord lastes opp i http://mc.manuscriptcentral.com/tidsskriftet.

Redaksjonen forbeholder seg retten til å foreta redaksjonelle endringer.

Forfattere av vitenskapelige artikler har tilsvarsrett (jf. Vancouver-gruppens regler).

\section{Galt om Kant}

I Tidsskriftet nr. 7/2011 hevdes det $\mathrm{i}$ et intervju med noen forskere ved Norges teknisk-naturvitenskapelige universitet at «filosofen Immanuel Kant allerede i 1781 mente at noen egenskaper ved kognisjon, såkalte a priori-egenskaper, ikke kunne komme fra erfaring, men måtte være medfødt. Kant mente bl.a. at kunnskap om rommet er til stede hos oss mennesker før vi har gjort oss noen erfaringer om det, ...» (1). Dette er galt. Kant benekter at hans aprioriske former for erfaringen er medfødte. I Stridsskriftet fra 1790 uttrykker han dette slik: «Kritikken tillater overhodet ingen gudskapte eller medfødte forestillinger; absolutt alle sammen, hva enten de hører til anskuelsen eller forstandsbegrepene, tar den for å være ervervet» (2). Kant sier i fortsettelsen at de aprioriske formene for erfaringen - rom, tid og forstandsbegrepene - er opprinnelig ervervet.

Avvisningen av medfødt kunnskap betones også i begynnelsen av innledningen til Kritikk av den rene fornuft: «At all vår erkjennelse begynner med erfaringen, kan det slett ikke være noen tvil om. (...) Men selv om nå all vår erkjennelse begynner med erfaringen, så utspringer den allikevel ikke derfor i sin helhet $a v$ erfaringen» (3, B1).

Det som er a priori, går forut for erfaringen i en logisk, ikke i en temporal forstand. Rom, tid og kategoriene er opprinnelig ervervede betingelser for at vi skal kunne få empirisk kunnskap om verden gjennom måling, observasjon og eksperiment, og derfor a priori.

I artikkelen i Science har forskerne hengt en henvisning til Kant på denne setningen: «it has remained unclear whether rat pups form any representation of the local environment at the onset of outbound exploration, (...) as would be expected if the spatial representation system is preconfigured» (4). De bruker her «representation» («Vorstellung») annerledes enn Kant. I hans betydning kan ikke en rotte ha en forestilling om rom og romlige forhold: «Vi kan følgelig bare snakke om rom, utstrakte vesener, osv. fra et menneskes standpunkt» (3, B42).

Betyr det at forskernes empiriske resultater har tilbakevist Kant? Neppe. Å benekte medfødte forestillinger er selvsagt ikke å benekte at medfødte nevrologiske systemer ligger til grunn for ervervelsen av forestillinger i en kognitiv forstand.

Forskerne tar for gitt en seiglivet populærfilosofisk myte om Kants filosofi som vi nedlegger mye arbeid i å avlære studentene ved examen philosophicum og andre filosofiske kurs ved Universitetet i Oslo. Henvisningen til Kant er sikkert gjort i beste mening, men i bunn og grunn dreier dette seg om å vise respekt for andre fag.

\section{Jens Saugstad}

jens.saugstad@ifikk.uio.no

Jens Saugstad (f. 1956) er dr.philos. og professor i filosofi ved Universitetet i Oslo.

\section{Litteratur}

1. Hem E. Kartlegging av hjernens navigasjonssystemer. Tidsskr Nor Legeforen 2011: 131: 654

2. Kant I. Über eine Entdeckung, nach der alle neue Kritik der reinen Vernunft durch eine ältere entbehrlich gemacht werden soll. I: Der Deutschen Akademie der Wissenschaften, red. Kant's gesammelte Schriften. Bd. 8. Berlin: Walter de Gruyter, 1902-: 221 .

3. Kant I. Kritik der reinen Vernunft. I: Der Deutschen Akademie der Wissenschaften, red. Kant's gesammelte Schriften. Bd. 3. Berlin: Walter de Gruyter, 1902

4. Langston RF, Ainge JA, Couey JJ et al. Development of the spatial representation system in the rat. Science 2010; 328: 1577

\section{Forbedring krever gode data}

Mette Walberg, smittevernoverlege i Vestre Viken, har i Tidsskriftet nr. 7/2011 (1) redegjort for et systematisk og godt arbeid med smittevern på Bærum sykehus. I artikkelen er hun kritisk til at vi har valgt å bruke prevalensmålinger for å følge måloppnåelse av ett av fem prioriterte mål som Helse SørØst har satt for perioden 2011-14, nemlig å redusere forekomsten av sykehusinfeksjoner til under $3 \%$.

Prevalens er her et mål på andelen pasienter i institusjonen med helsetjenesteassosierte infeksjoner på et gitt tidspunkt, mens insidens måler antall nye tilfeller av en sykdom i en gitt periode. For Helse SørØst falt valget for 2011 på punktprevalens fordi det er en mer allment kjent og enklere målemetode og fordi hvert helseforetak/ sykehus ville ha tidligere resultater å sammenlikne med. I brev til alle helseforetakene av 3.2. $2011 \mathrm{i}$ år ba vi dem derfor om å gjennomføre den første prevalensundersøkelsen 16. februar. Sammen med de to undersøkelsene fra 2010 ville resultatet være en utgangsverdi for helseforetaket for å kunne måle effekten av tiltakene som blir iverksatt i 2011 og som de skal følge opp med nye prevalensundersøkelser i mai, september og november, i samsvar med Folkehelseinstituttets opplegg. Vi har i brevet også omtalt at det i løpet av 2011 vil bli videreutviklet metodikk, indikatorbruk og målemetoder for å gå over til insidensmålinger fra 2012, slik Helsedirektoratet har planlagt. Dette vil skje i nært samarbeid med vårt regionale fagråd for infeksjonsmedisin, immunologi og smittevern.

Helse Sør-Øst har på denne måten valgt å legge vekt på og prioritere smittevernarbeid i det enkelte helseforetak, i tråd med den nasjonale pasientsikkerhetskampanjen. Hvert foretak skal utarbeide egne tiltaksplaner for å sikre at regionen når det ambisiøse målet om en halvering av forekomsten av sykehusinfeksjoner i løpet fireårsperioden. Vi har også bedt om at disse planene blir styrebehandlet. Vi er helt enige med Walberg $i$ at insidensmålinger gir et bedre sammenlikningsgrunnlag for å se forskjeller eller likheter mellom ulike avdelinger og institusjoner. Inntil rutiner for insidensmålinger blir mer utviklet og bedre innarbeidet har vi likevel valgt å følge Folkehelseinstituttets praksis med prevalensundersøkelser, fordi de gir et godt alternativ for å registrere og vurdere effekten av det lokale smittevernarbeidet. Disse målingene er sykehusene godt kjent med, og for 2011 har vi $ø \mathrm{kt}$ antall prevalensundersøkelser fra to til fire, for at hvert sykehus skal få flere målepunkter for å følge resultatene av egne tiltak.

Helse Sør-Øst er svært tilfreds med at det drives et aktivt og godt smittevernarbeid i Vestre Viken og vil bidra til at de erfaringer og resultater som Walberg omtaler, skal komme alle helseforetakene i regionen til gode. Det passer svært godt med at vi nå har prioritert dette området og har et felles mål om å redusere forekomsten av sykehusinfeksjoner som et ledd i arbeidet med å bedre pasientbehandlingen og -sikkerheten. I denne videreutviklingen vil anbefalingene fra fagrådet være svært viktige for oss.

\section{Bente Mikkelsen}

postmottak@helse-sorost.no

Bente Mikkelsen (f. 1959) er spesialist i fødselshjelp og kvinnesykdommer og administrerende direktør i Helse Sør-Øst RHF.

Litteratur

1. Walberg M. Forbedring krever gode data. Tidsskr Nor Legeforen 2011; 131: 208. 